\title{
ARTICLE
}

\section{Alu-splice cloning of human Intersectin (ITSN), a putative multivalent binding protein expressed in proliferating and differentiating neurons and overexpressed in Down syndrome}

\author{
Carles Pucharcós ${ }^{1}$, Juan-José Fuentes ${ }^{1}$, Caty Casas $^{1}$, Susana de la Luna ${ }^{1}$, \\ Soledad Alcántara $^{2}$, Maria L Arbonés ${ }^{1}$, Eduardo Soriano $^{2}$, Xavier Estivill ${ }^{1}$ and \\ Melanie Pritchard ${ }^{1 *}$ \\ ${ }^{1}$ Down Syndrome Research Group, Medical and Molecular Genetics Center, IRO, Hospital Duran i Reynals, \\ L'Hospitalet de Llobregat, Barcelona \\ ${ }^{2}$ Department of Animal and Plant Cell Biology, Faculty of Biology, University of Barcelona, Barcelona, Spain
}

\begin{abstract}
By Alu-splice PCR we have trapped two exons and subsequently identified the full length cDNA of a human gene, Intersectin (ITSN), which maps to chromosome 21q22.1 between markers D21S320 and D21S325. The gene has the potential to code for at least two different protein isoforms by alternative splicing (ITSN-L and ITSN-S). Intersectin exists with a high degree of similarity in flies, frogs and mammals, suggesting a conserved role in higher eukaryotes. Analysis of the expression pattern of human and mouse Intersectin detected mRNAs in all adult and foetal tissues tested, with the longer isoform present in brain. In situ hybridisation studies in the developing mouse brain showed ITSN expression in both proliferating and differentiating neurons. The genomic structure of ITSN was determined using the chromosome 21 sequences deposited in the public databases. The protein contains several known motifs which implicate ITSN in clathrin mediated endocytosis and synaptic vesicle recycling. The expression pattern of Intersectin in mouse brain, its presumed function and its overexpression in brains from Down syndrome patients, suggest that Intersectin may contribute in a gene dosage-dependent manner to some of the abnormalities of Down syndrome.
\end{abstract}

Keywords: Intersectin; chromosome 21q22; Down syndrome; endocytosis

Correspondence: Dr X Estivill, Down Syndrome Research Group, Medical and Molecular Genetics Center, IRO, Hospital Duran i Reynals, Avia. de Castelldelfels Km 2.7, L'Hospitalet de Llobregat, 08907 Barcelona, Spain. Tel: +34 93 2607775; Fax: + 3493 2607776; E-mail: estivill@iro.es

*Present address: Molecular Genetics \& Development Group, Institute of Reproduction \& Development, Monash University, Clayton, Victoria 3168, Australia.

Received 30 December 1998; revised 17 March 1999; accepted 7 April 1999 


\section{Introduction}

Down syndrome (DS) or trisomy 21 is the most common chromosomal aneuploidy that comes to term in humans. With an incidence of 1 in 700 live births DS is the most frequent genetic cause of mental retardation. ${ }^{1}$ DS affects every major organ system in the body and includes many abnormalities, such as an increased risk of childhood leukaemias, congenital heart and gastrointestinal tract defects, and characteristic cranofacial anomalies. DS individuals also develop Alzheimer-like amyloid plaques and neurofibrillary tangles by approximately the third decade of life, with a significant number of these patients developing presenile dementia. $^{2}$

The most likely consequence of three copies of human chromosome 21 is the overexpression of the genes on this chromosome. Therefore, the DS phenotype presumably results from a perturbation of the interactions of these chromosome 21 gene products with their usual targets, due to the increased gene dosage. One of the major aims of DS research is to identify the roles of individual genes in specific pathologies that occur as part of the DS phenotype. The isolation and characterisation of these genes is the first step in understanding the biochemical and molecular bases for these pathologies and this information is crucial for the development of therapeutic strategies.

Human chromosome 21 is estimated to contain 600-1000 genes. International gene cloning efforts have led to the identification of numerous genes and transcriptional units ${ }^{3-11}$ and, more recently, large scale sequencing (http://www-eri.uchsc.edu/chr21/eridna. html) has enabled the prediction of many more. However, even though 112 genes (GDB, 20 September 1998) have been assigned to chromosome 21 , the functions of most of these genes remain largely unknown, as does their contribution, if any, to the DS phenotype.

With the aim of contributing to the transcriptional map of human chromosome 21 we developed a technique to isolate expressed sequences called $A l u$-splice PCR, ${ }^{12}$ and trapped two exons of the gene that we report here called human Intersectin (ITSN). During the preparation of this manuscript the human Intersectin gene was published ${ }^{13}$ and we concur with all aspects. The assembly of the partial clones we obtained by cDNA library screening and RACE gave rise to a continuous 6439 bp long cDNA with an open reading frame of 1721 amino acids, a 5'-UTR of $268 \mathrm{bp}$ and a 3'-UTR of $1005 \mathrm{bp}$ lacking a clear consensus poly- adenylation signal. We also identified a shorter form of ITSN arising from an alternative splicing event which would encode the first 1220 amino acids of Intersectin. The 3'-UTR of this isoform was $1450 \mathrm{bp}$ and had several consensus polyadenylation signals. We refer to the two different isoforms as Intersectin long (ITSN-L) and short (ITSN-S). ITSN-L was expressed specifically in brain (adult and foetal) and gave a transcript of about $11 \mathrm{~kb}$, whilst $I T S N-S$ was expressed in all the tissues tested and gave a predominant band of about $6 \mathrm{~kb}$ with a less abundant transcript of $5 \mathrm{~kb}$ in some tissues.

Database searches revealed that the predicted ITSN polypeptide shared $81 \%$ amino acid identity with Xenopus leavis intersectin ${ }^{14}$ (GenBank acc. no. AF032118). A partial sequence of the gene (SH3P17, GenBank acc. no. U61166) had also been reported in a screening of SH3 domain-containing proteins ${ }^{15}$ and later on was mapped to chromosome $21 .{ }^{16,17}$ ITSN was also similar to two Drosophila proteins, Dap160-1 and Dap160-2. ${ }^{18}$ A number of functional domains are present in the protein. ITSN posesses two EH domains or Eps15 homology domains which are involved in protein-protein interactions and are frequently present in multiple copies. ${ }^{19}$ Most of the EH-containing proteins, such as mammalian Eps $15^{20}$ and yeast End3p, ${ }^{21}$ have been linked to endocytic pathways. The central part of the protein has five consecutive Src homology 3 (SH3) domains. ${ }^{22} \mathrm{SH} 3$ domains are commonly found in signal transduction and cytoskeletal proteins. They mediate protein-protein interactions by binding to proline rich peptides. ${ }^{23}$

The carboxy terminus specific to the long ITSN isoform contains three well described domains. The first matches a Dbl homology (DH) domain. DH domains are regions of about 180 amino acids which serve as the catalytic regions of guanine nucleotide exchange factors (GEF) for Rho-like GTPases. ${ }^{24}$ As in all the other DH domain-containing proteins, the ITSN DH domain is followed by a pleckstrin homology $(\mathrm{PH})$ domain. $\mathrm{PH}$ domains are conserved protein modules of about 100 amino acids. ${ }^{25}$ They mediate membrane phosphoinositide interactions and in some cases they may function in protein-protein interactions. Many of the PH domain-containing proteins are involved in regulating intracellular signalling pathways or the cytoskeleton. ${ }^{26}$ The most carboxy region of the long isoform has sequence homology with $\mathrm{C} 2$ domains. ${ }^{27}$ The $\mathrm{C} 2$ domain is a calcium-binding motif which is widely distributed among eukaryotic proteins including lipid modifying 
enzymes, protein kinases, GTPases and proteins involved in membrane trafficking. Thus, human Intersectin encodes a putative multi-modular protein with several conserved domains that suggest it is related to proteins involved in clathrin mediated endocytosis and synaptic vesicle recycling.

Here, in addition to the above, we report that ITSN is expressed early in mouse development and in situ hybridisation in mouse brains shows that Intersectin is expressed in many areas of the developing and adult brain. Moreover, the human Intersectin gene is overexpressed in DS and, as such, is a candidate for some of the clinical aspects of the pathogenesis of this chromosomal aneuploidy.

\section{Materials and Methods}

\section{cDNA Cloning and Sequencing}

The original clone 860g11-76 (GenBank acc. no. U84494) was isolated by $A l u$-splice PCR using the human chromosome 21 YAC 860G11 as template, the Alu primer SalI-A33 (5'-CGCGTCGACCACTGCACTCCAGCCTGGGCG-3') and the splice primer NotI-5' spl (5'-CGCGCGGCCGCACWYACCW-3'), where $\mathrm{W}$ represents $\mathrm{A}$ or $\mathrm{T}$ and $\mathrm{Y}$ represents $\mathrm{T}$ or $\mathrm{C}$ ), using the same conditions described in Fuentes $e t$ $a l .{ }^{12}$ PCR products were cloned in pBluescript SK (Stratagene, La Jolla, USA). This clone was used as a probe for isolating a full-length cDNA by a combined approach of cDNA library screening and RACE. Protein analysis for domain and pattern recognition was carried out using the following public programs: Profilescan (http://www.isrec.isbsib.ch/software/PFSCAN_form.html), SMART ${ }^{28}$ (http://coot .embl-heidelberg.de/SMART) and Motif (http://www.motif. genome.ad.jp).

\section{Northern Blotting}

A northern blot containing poly $\mathrm{A}^{+}$RNA from mouse embryos of different developmental stages (Cat. No. 7763-1) was purchased from Clontech (Palo Alto, USA). Northern blots were prehybridised in a buffer containing $5 \times$ SSPE, $10 \times$ Denhardt's, $2 \%$ SDS and $100 \mu \mathrm{g} / \mathrm{ml}$ salmon sperm DNA for $3 \mathrm{~h}$ at $65^{\circ} \mathrm{C}$. Hybridisation was in the same buffer at $65^{\circ} \mathrm{C}$ for $16 \mathrm{~h}$ with the probe indicated in the Results section. Blots were washed sequentially in $2 \times$ SSC- $0.1 \%$ SDS, $1 \times$ SSC$0.1 \%$ SDS, $0.5 \times$ SSC- $0.1 \%$ SDS and $0.2 \times$ SSC- $0.1 \%$ SDS, at $60^{\circ} \mathrm{C}$ for $20 \mathrm{~min}$ each and exposed to X-ray film for 3 to 10 days at $-70^{\circ} \mathrm{C}$.

\section{RNA Isolation and Semiquantitative RT-PCR}

Total RNA was extracted from prosencephalon of 18-22 weeks' gestation DS and non-DS foetal abortusses using the RNeasy Kit (Qiagen GmbH, Gilden, Germany). In both cases, the RNA was a mixture from two individuals. Tissue was obtained in accordance with institutional guidelines and for all the cases the post-mortem period was less than $12 \mathrm{~h}$. cDNA was synthesised by reverse transcription of $3 \mu \mathrm{g}$ of total RNA using the Ready-to-Go kit (Pharmacia Biotec, Uppsala, Sweden) and random hexamers as primers, according to manufacturer's recommendations. One $\mu l$ of the
cDNA first strand synthesis was used as a template in a PCR reaction with human ITSN-L-specific primers 6 (5'-TTCTCCCCGGACATCTTCTT-3') and 7B (5'-TCAGAGGGCTCTGGAACTGCT-3') and glyceraldehyde phosphate dehydrogenase $(G A P D H)$ primers ${ }^{29}$ using the following cycle conditions: $95^{\circ} \mathrm{C}$ for $30 \mathrm{~s}, 59^{\circ} \mathrm{C}$ for $30 \mathrm{~s}$ and $74^{\circ} \mathrm{C}$ for $50 \mathrm{~s}$, for 16, 20, 23 and 27 cycles. Controls were performed under the same conditions with 25 amplification cycles. Products were run on a $2 \%$ agarose gel, stained with ethidium bromide and photographed.

\section{RNA in situ Hybridisation}

In situ hybridisation was performed on free-floating sections essentially as described. ${ }^{30}$ Embryos (stage E16) and postnatal OF1 mice (Iffa Credo, Lyon, France) were used in this study. Embryos and adults were transcardially perfused with $4 \%$ paraformaldehyde in phosphate buffered saline (PBS) and their brains were postfixed. After cryoprotection with $30 \%$ sucrose, brains were frozen on dry ice and cut in coronal sections (thickness: $60 \mu \mathrm{m}$ E16 and $30 \mu \mathrm{m}$ adult). Sections were collected in a cryoprotective solution $(30 \%$ glycerol$30 \%$ ethylenglycol- $40 \%$ PBS) and stored at $-80^{\circ} \mathrm{C}$ until use.

The mouse IMAGE clone 482370 was used to synthesise the riboprobes. ${ }^{31}$ Sense and antisense riboprobes were generated on a linear fragment of the clone obtained by PCR using M13 primers. The DIG RNA labelling kit (Boehringer Mannheim GmbH, Mannheim, Germany) was used with either T3 or T7 RNA polymerase.

\section{Results}

\section{Structure of ITSN}

Two forms of human Intersectin were isolated using the Alu-splice clone 860g11-76 (accession no. U84494). ${ }^{12}$ The sequences of the two forms, ITSN-L and ITSN-S are deposited in GenBank with accession nos. AF114487 and AF114488, respectively and are identical to the sequences reported by Guipponi and colleages. ${ }^{13}$ The ITSN cDNA sequence was contained within the genomic sequences present in the GenBank database entries AP000048, AP000049 and AP000050 derived from chromosome 21 and deposited by Sakaki and co-workers. Comparison of these sequences with the ITSN cDNA allowed us to elucidate its genomic organisation. ITSN consists of at least 41 exons (Table 1), spans more than $233 \mathrm{~kb}$ of genomic DNA between markers D21S320 and D21S325 and is transcribed in the 21cen- $>$ qter direction. All the introns have canonical splice donor and acceptor sites (Table 1). The genomic structure enabled us to confirm that the generation of the long isoform is the result of an alternative splicing event in which exon 29, which provides the stop codon for the short isoform when joined to exon 28, is skipped. Sequence analysis of human Intersectin ESTs, as well as SH3P17, which 
variously lack exons 19, 24 and 25, revealed that other alternatively spliced mRNAs may exist.

\section{Expression of Mouse Intersectin mRNA}

Searches of mouse EST databases identified several putative murine Intersectin homologue clones. One of these, IMAGE clone 482378 (GenBank acc. no. AA063751) was used as a hybridisation probe with a foetal mouse northern blot containing four mouse embryo developmental stages (Figure 1) to define the time course of expression during development. As in the human northerns, the probe detected bands of $5 \mathrm{~kb}$, $6 \mathrm{~kb}$ and $11 \mathrm{~kb}$, suggesting a high degree of conservation and demonstrating that the brain-specific splicing event is conserved in the mouse. For the $5 \mathrm{~kb}$ and $6 \mathrm{~kb}$ transcripts, expression was first detected at day 11 of mouse foetal development, whilst the $11 \mathrm{~kb}$ transcript was first visible by northern at day 17 . Since the RNA on the blot is derived from the whole mouse embryo, the relative amount of the brain-specific transcript is high.

Table 1 Exon-intron boundaries of human ITSN

\begin{tabular}{|c|c|c|c|c|c|}
\hline$\overline{\text { Exon }}$ & Size $(b p)$ & $5^{\prime}$ splice donor $^{\mathrm{a}}$ & Intron & Size (bp) & $3^{\prime}$ splice applicator $^{\mathrm{a}}$ \\
\hline-1 & $>236$ & TGAGgtgagg & -1 & $>62184^{b}$ & attttcacttacagGCGT \\
\hline 1 & 60 & GGTGgtaagt & 1 & 2321 & tctttggattttagGCAG \\
\hline 2 & 93 & ACTGgtaatc & 2 & 1317 & tgtttaatttacagGTGA \\
\hline 3 & 64 & TATGgtaagt & 3 & 12392 & ctgttggtttgcagGGCA \\
\hline 4 & 161 & TTTGgtaagt & 4 & 14938 & ttttttcttcatagGTAT \\
\hline 5 & 180 & CCTGgtatgt & 5 & 1487 & atttatttttacagCAGC \\
\hline 6 & 97 & CCAGgtaagt & 6 & 3390 & tcttttccccacagTGTC \\
\hline 7 & 101 & ACAGgtattt & 7 & 6524 & tggttcctgtttagGTCC \\
\hline 8 & 64 & TATGgtaagg & 8 & 3888 & tttttgttgaatagGAAT \\
\hline 9 & 138 & TTAGgtaagg & 9 & 1700 & ccccgcaattgcagAAGA \\
\hline 10 & 116 & CCTGgtaagg & 10 & 4232 & ttccttgtctgaagTAAC \\
\hline 11 & 236 & AGAGgtaagc & 11 & 2405 & tgtaaatgtcacagGCTG \\
\hline 12 & 150 & TCTAgtgagt & 12 & 89 & ttcatttgttcaagAATG \\
\hline 13 & 141 & ACAGgtgagg & 13 & 6352 & tccttccttcccagGAAT \\
\hline 14 & 88 & CACAgtaggt & 14 & 445 & tttttctaaaatagGAGA \\
\hline 15 & 140 & GAAGgtaact & 15 & 12207 & tcggttaattatagGAAC \\
\hline 16 & 128 & AAAGgtgagt & 16 & 2910 & gtgtttgttggcagACGA \\
\hline 17 & 230 & GCAGgtatta & 17 & 2199 & ttttttgtaaacagAAAA \\
\hline 18 & 122 & CATGgtaaga & 18 & 2500 & ctttcctggtggagGTTA \\
\hline 19 & 15 & ATGGgtaagt & 19 & 8530 & gacttttccacagGTGG \\
\hline 20 & 248 & CCAGgtacgt & 20 & 2690 & gcttttccctccagGTGG \\
\hline 21 & 160 & CCAGgtaaag & 21 & 4194 & ttattccacacaagGGTG \\
\hline 22 & 206 & CAAGgtattt & 22 & 768 & ttccattattgcagCATG \\
\hline 23 & 83 & GAAGgtgagg & 23 & 4163 & tttctccccaccagAATT \\
\hline 24 & 167 & AGAGgtaaac & 24 & 3164 & tgctctgttttaagGGCT \\
\hline 25 & 46 & CCTGgtaagt & 25 & 2760 & atcttgtttttcagAAAT \\
\hline 26 & 122 & GCAAgtcagt & 26 & 4561 & tattttcttactagGCAC \\
\hline 27 & 118 & GCAGgtaagg & 27 & 2016 & cctgtctcctgcagTGTG \\
\hline 28 & 192 & CAATgtaagt & 28 & 354 & cctcctttttctagGAAT \\
\hline 29 & $>1453$ & - & 29 & 18246 & gttgtgttttccagGGTG \\
\hline 30 & 122 & AGAGgtaagg & 30 & 1828 & ttctgcatctgtagATTT \\
\hline 31 & 107 & TAAAgtaagc & 31 & 6358 & gtgtttccgtgcagAGCG \\
\hline 32 & 184 & CAAAgtaagg & 32 & 1898 & acatctcatttcagAGAT \\
\hline 33 & 99 & AAATgtaagt & 33 & 8022 & attctcctgtgtagATCC \\
\hline 34 & 168 & TGAGgtagcc & 34 & 6721 & ttttcctttctcagCAAC \\
\hline 35 & 213 & AACAgtaagt & 35 & 1094 & gtgttactttccagCCTA \\
\hline 36 & 122 & AAAGgtgaga & 36 & 1369 & tttttctgtccaagGACT \\
\hline 37 & 83 & CTGGgtaatg & 37 & 315 & tcctgccgtcatagTCCG \\
\hline 38 & 84 & CATGgtaagg & 38 & 764 & tttgttccctccagGAAA \\
\hline 39 & 174 & GATGgtgagt & 39 & 1691 & tgttctcttttcagATTT \\
\hline 40 & $>1154$ & - & & - & \\
\hline
\end{tabular}

${ }^{a}$ Nucleotides from exon (u.c.); from intron (l.c.). Conserved splice donor and acceptor sites are in bold.

${ }^{\mathrm{b}}$ The exact size of intron -1 is unknown as the genomic sequence deposited for this region is incomplete 
To analyse further the pattern of Intersectin expression in the developing and adult mouse brain, we performed in situ hybridisation studies (Figure 2). At embryonic day 16 (E16), Intersectin mRNA was widely distributed in different regions of the brain. For instance, in the forebrain, high expression levels were detected in the neocortex, hippocampus, septum and striatum (Figure 2A). Expression was observed both in the proliferative layers (eg ventricular zone in the cerebral cortex), as well as in the differentiating fields where postmitotic neurons are undergoing maturation (eg the cortical plate in the cerebral cortex). Intersectin mRNA expression was also detected in other areas, such as in discrete nuclei of the thalamus, mesencephalon, and rhombencephalon (Figure 2B). The gene was also expressed in the developing cerebellum and spinal cord (data not shown). These observations show that Intersectin is expressed in both proliferating and differentiating neurons.

In the adult murine brain, Intersectin was expressed in many neuronal populations in the forebrain, midbrain and hindbrain. In the cerebral cortex, for instance, transcripts were detected in all the layers of the neocortex as well as in the pyramidal neurons and granule cells of the hippocampus and the dentate gyrus, respectively (Figure 2C). Expression was also observed in the olfactory bulb, striatum, thalamus, brain stem and cerebellum, where the Purkinje cells were labelled (Figure 2D). Taking into account all these data, we can conclude that Intersectin is widely expressed in both the developing and adult brain.

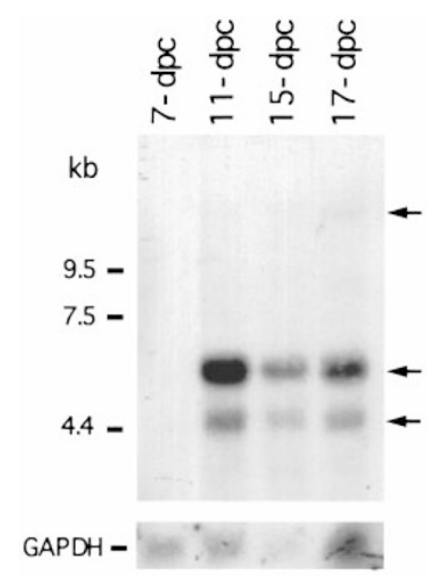

Figure 1 Expression analysis of mouse Intersectin by northern blot hybridisation. Northern blot containing $2 \mu \mathrm{g}$ of poly $A^{+}$from mouse embryos of $7 d p c, 11 d p c, 15 d p c$ and $17 d p c$ was hybridised with IMAGE clone 482370. A GAPDH control hybridisation is shown below

\section{Analysis of ITSN Expression in Down Syndrome}

We compared the level of expression of ITSN in brains from DS and non-DS foetuses. We carried out a semiquantitative RT-PCR on RNA prepared from prosencephalon. We used $G A D P H$ primers $^{29}$ as control primers, which produced a band of $496 \mathrm{bp}$, and ITSNspecific primers, which produced a band of $748 \mathrm{bp}$ from the brain-specific long isoform (Figure 3 ). The results clearly show that ITSN-L is overexpressed in the brains of DS foetuses compared with controls.

\section{Discussion}

We have reported the identification and isolation of a novel chromosome 21 gene, Intersectin (ITSN), so named because of its great similarity ( $81 \%$ amino acid identity) to Xenopus intersectin. The human gene codes for at least two transcripts, the larger being the product of a brain-specific splicing event. The two proteins differ in the length of their carboxy termini, and thus the larger isoform contains extra functional domains. Two of the exons of human Intersectin were identified by $A l u$-splice PCR, which we have demonstrated is a powerful method for the isolation of exons from large genomic clones. $^{12,32}$

Xenopus intersectin interacts via its $\mathrm{SH} 3$ domains with dynamin (a GTPase) and synaptojanin 1, proteins identified as components of the recycling machinery of synaptic vesicles in nerve terminals. ${ }^{33}$ It also binds two mouse proteins, Ibp1 and Ibp2 through its $\mathrm{EH}$ domain. ${ }^{14}$ Ibp1 is the murine homologue of human epsin, ${ }^{34}$ a protein concentrated in presynaptic nerve terminals which binds the $\alpha$-adaptin subunit of AP-2 and the clathrin-coat-associated protein Eps15. Human Intersectin showed a great similarity to two Drosophila proteins Dap 160-1 and Dap 160-2. ${ }^{18}$ Dap 160 was isolated as a dynamin associated protein and identified as a membrane protein present in resting endocytic hot spots in Drosophila nerve terminals. ${ }^{18}$ Thus, it is possible that Dap 160, Xenopus intersectin and human Intersectin are members of a family of proteins which may serve as scaffolding proteins required for clathrinmediated endocytosis.

In humans, a long, brain-specific isoform of ITSN exists. This isoform is also present in the mouse, suggesting an essential role for this species in the brain throughout development and adulthood. This long isoform of human Intersectin has the extra capacity to encode DH, PH and C2 motifs. The DH (or Dbl) 

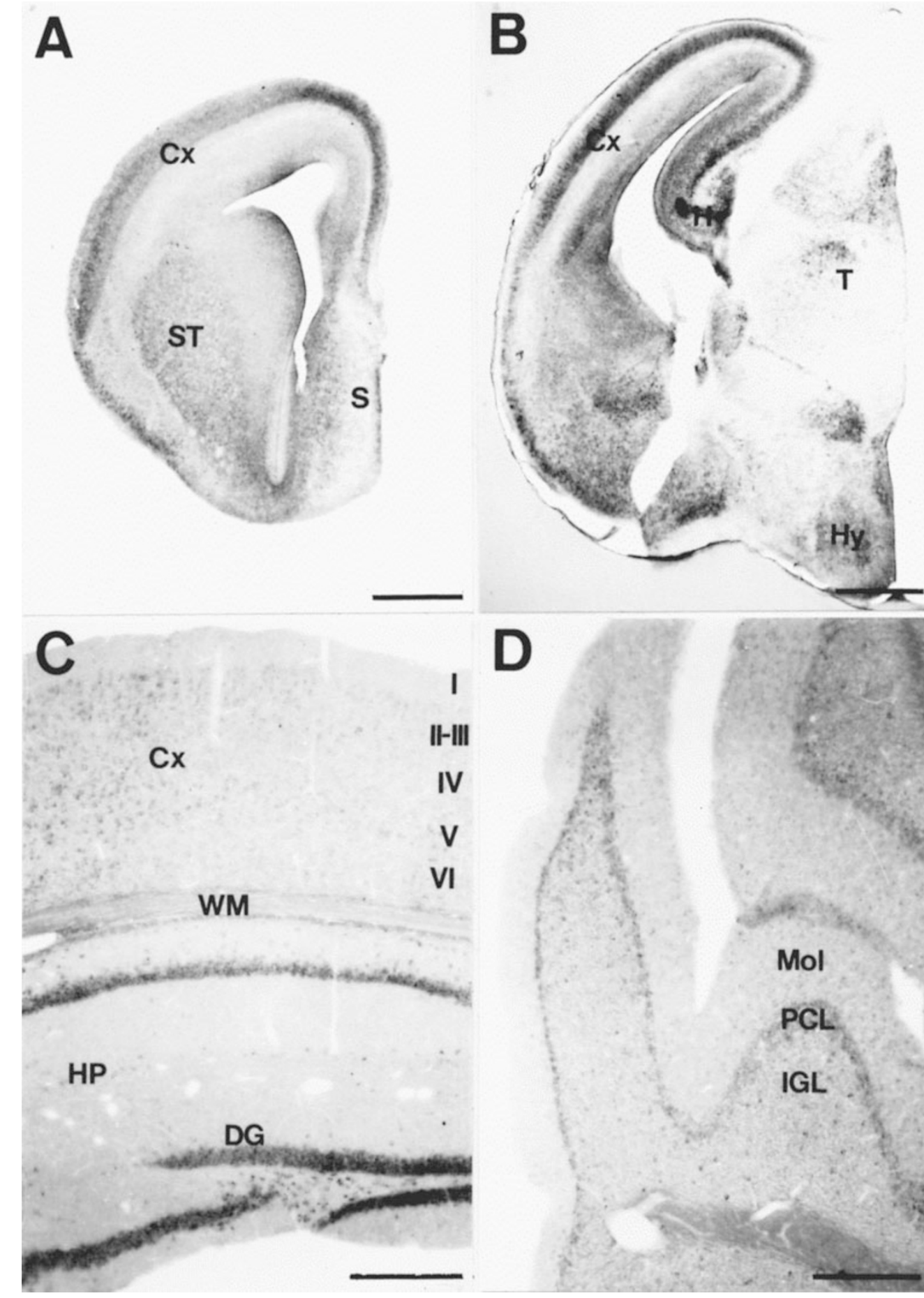

\section{D}

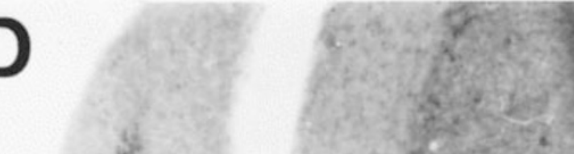

\section{III}

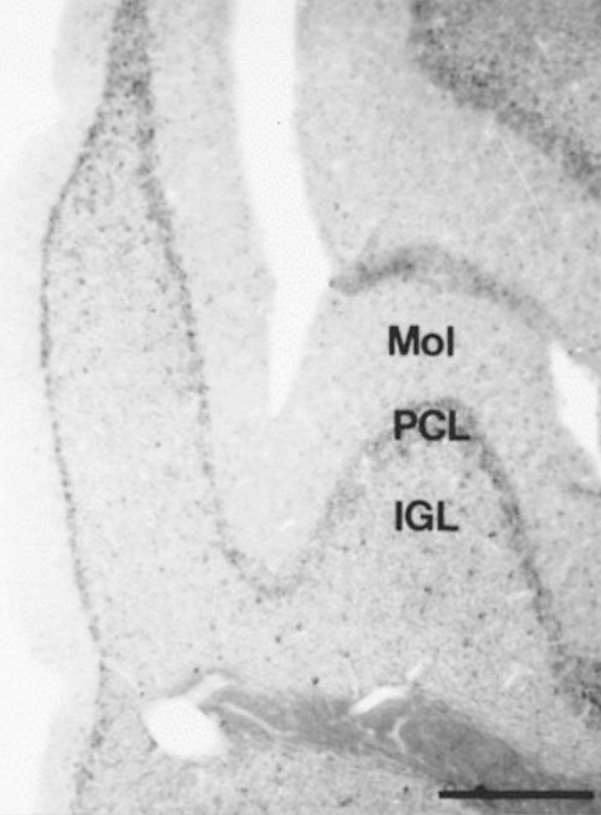

Figure 2 In situ hybridisation analysis. Low-power views illustrating the main features of Intersectin $m R N A$ distribution in coronal sections at E16 $(A, B)$ and in the adult central nervous system $(C, D)$. (A) At rostral telencephalic levels Intersectin was expressed along the cerebral cortex (Cx), septum (S) and striatum (ST) at E16. (B) At E16 caudal telencephalic levels Intersectin $m R N A$ was found in the cerebral cortex, hippocampus $(H)$ and in some discrete thalamic $(T)$ and hypothalamic (Hy) nuclei. (C) In the adult cerebral cortex and hippocampus (HP) Intersectin $m R N A$ is widely distributed throughout the different layers. (D) Intersectin signal is detected in the Purkinje cells (PCL) and along the internal granular layer (IGL) in the adult cerebellum. DG, dentate gyrus; Mol, molecular layer; WM, white matter; I-VI, cortical layers. Scale bar A, B: $500 \mu m ; C, D: 300 \mu m$ 
domain is the region in guanine-nucleotide exchange factors that catalyses an exchange of GTP for GDP on Rho-like G proteins. ${ }^{35}$ Interestingly, Rho and Rac have been shown to function in regulating endocytosis. ${ }^{36} \mathrm{C} 2$ domains are regulatory sequence motifs that occur widely in nature and although they were initially described as calcium-binding motifs, they have also been shown to bind phosphoinositides. ${ }^{27}$ Synaptotagmin I, a synaptic vesicle protein involved in calcium regulation of endocytosis, contains two $\mathrm{C} 2$ domains, one of which acts as a calcium sensor. ${ }^{37}$ Although it is difficult to speculate about how these domains may come together in a functional Intersectin protein, their unifying feature is that they are all found in proteins involved in membrane trafficking.

The primary function of the synaptic vesicle is neurotransmitter release, or exocytosis. After exocytosis, the components of the synaptic vesicle membrane are selectively recovered by endocytosis and recycled within the nerve terminal to generate new synaptic vesicles. This local recycling pathway allows neurons to maintain a constant supply of synaptic vesicles and this recycling capacity is essential for the consistent release of neurotransmitter. The process of docking, fusion and endocytosis are not restricted to the nerve terminal, they are elements of membrane-trafficking pathways in all eukaryotic cells. However, in non-neuronal cells

\section{A}

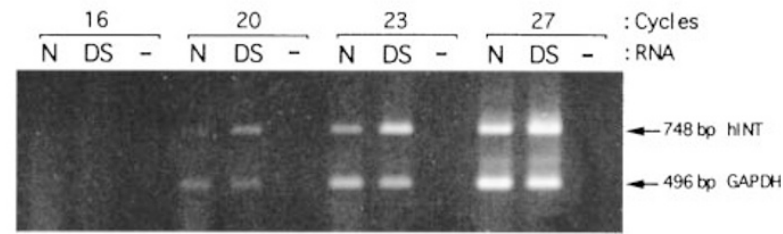

B

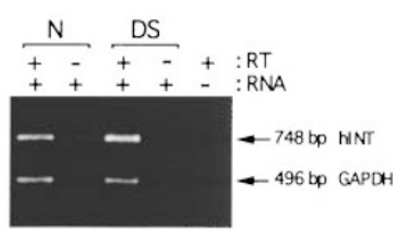

Figure 3 Comparison of the RNA expression of ITSN1-L in human brains from DS and non-DS foetuses. (A) Semiquantitative RT-PCR reactions were performed using as template total RNA from the brains of two Down syndrome foetuses $(D S)$ and two non-Down syndrome foetuses (N) for the indicated number of cycles. ITSN primers produce a $748 \mathrm{bp}$ band and GAPDH control primers produce a 496 bp band. In lanes 3, 6, 9 and 12, controls without RNA were included. (B) Controls of the RT-PCR reactions. A set of control reactions on total RNA from the brains of DS and non-DS foetuses amplified with and without reverse transcriptase most of these events are constitutive. ${ }^{38}$ Therefore, additional mechanisms must account for the special temporal, spatial and calcium-sensitive properties of transmitter release and recycling, and the speed at which they occur. Consistent with the ubiquitous expression of the short Intersectin isoform, we propose that $I T S N-S$ is involved in the generalised endocytic pathways of all cells and that the long isoform, ITSN-L, has been endowed with the more specialised properties required for brain-specific synaptic vesicle recycling.

Genes which show expression during development or, more particularly, in the developing brain may be of special importance in DS. Moreover, processes involving proteins with the capacity to interact with a myriad of other gene products may be more susceptible to the effects of dosage imbalance. Intersectin is expressed in the human foetus and in the developing mouse embryo. The long isoform was clearly overexpressed in the developing brains of foetuses with DS. At present, we can only speculate on the significance of this. Abnormal synaptic parameters have been reported in DS brains, including changes that could lead to a reduced efficiency of synaptic transmission. ${ }^{39,40}$ In the brain of the Ts65Dn mouse (a mouse model for DS) impaired cAMP production, alterations in central noradrenergic transmission and reduced LTP (long term potentiation) have been found. ${ }^{41-43}$ Both LTP and cAMP are associated with enhanced synaptic transmission which involves either increased transmitter release or increased receptivity to released transmitter. ${ }^{38}$ If Intersectin is involved in synaptic transmission, then it is feasible that the abnormal stoichiometry of such a multi-modular protein may lead to a decrease in transmission efficiency and have detrimental consequences in Down syndrome.

Although during the preparation of this manuscript the human Intersectin gene was published, ${ }^{13}$ we report additional information, specifically, the genomic structure of the human gene, a preliminary mouse Intersectin expression profile, including in situ hybridisation data, and the overexpression of Intersectin in DS.

\section{Acknowledgements}

We thank Dr JC Ferreres Piñas and Dr M Dierssen for providing human tissues, Dr L Sumoy for IMAGE clone 482370, and Dr S Larriba, M. Ruiz and members of the laboratory for helpful discussions. We also acknowledge Sakaki and colleagues for chromosome 21 sequences. SL has 
a postdoctoral grant from Spanish Ministerio de Educación y Ciencia. This study was supported by the European Union (CEC/BIOMED2 GENE-CT96-0054, BMH4-CT96-1364 and BMH4-CT98-3039), the Dirección General de Enseñanza Superior (PM95-0106-C02-01), the Fundació Catalana Síndrome de Down/Marató de TV3-1993 and the Servei Català de la Salut.CP and J-JF contributed equally to this work.

\section{References}

1 Hassold TJ, Jacobs PA: Trisomy in man. Annu Rev Genet 1984; 18: 69-97.

2 Epstein CJ: The Consequences of Chromosome Imbalance: Principles, Mechanisms and Models. Cambridge University Press: New York, 1986.

3 Peterson A, Patil N, Robbins C, Wang L, Cox DR, Myers RM: A transcript map of the Down syndrome critical region on chromosome 21. Hum Mol Genet 1994; 3: 1735-1742.

4 Cheng JF, Boyartchuk V, Zhu Y: Isolation and mapping of human chromosome 21 cDNA: progress in constructing a chromosome 21 expression map. Genomics 1994; 23: $75-84$.

5 Tassone $\mathrm{F}, \mathrm{Xu} \mathrm{H}$, Burkin $\mathrm{H}$, Weissman $\mathrm{S}$, Gardiner $\mathrm{K}$ : cDNA selection from $10 \mathrm{Mb}$ of chromosome 21 DNA: efficiency in transcriptional mapping and reflections of genomic organization. Hum Mol Genet 1995; 4: $1509-1518$.

6 Lucente D, Chen HM, Shea D et al: Localization of 102 exons to a $2.5 \mathrm{Mb}$ region involved in Down syndrome. Hum Mol Genet 1995; 4: 1305-1311.

7 Yaspo ML, Gellen L, Mott R et al: Model for a transcript map of human chromosome 21: isolation of new coding sequences from exon and enriched cDNA libraries. Hum Mol Genet 1995; 4: 1291-1304.

8 Chen H, Chrast R, Rossier C, Morris MA, Lalioti MD, Antonarakis SE: Cloning of 559 potential exons of genes of human chromosome 21 by exon trapping. Genome Res 1996; 6: 747-760.

9 Guimerà J, Pucharcós C, Domenech A et al: Cosmid contig and transcriptional map of three regions of human chromosome 21q22: identification of 37 novel transcripts by direct selection. Genomics 1997; 45: 59-67.

10 Ohira M, Seki M, Nagase T et al: Gene identification in 1.6-Mb region of the Down syndrome region on chromosome 21. Genome Res 1997; 7: 47-58.

11 Dahmane N, Ghezala GA, Gosset P et al: Transcriptional map of the 2.5-Mb CBR-ERG region of chromosome 21 involved in Down syndrome. Genomics 1998; 48: 12-23.

12 Fuentes JJ, Pucharcós C, Pritchard M, Estivill X: Alusplice PCR: a simple method to isolate exon-containing fragments from cloned human genomic DNA. Hum Genet 1997; 101: 346-350.

13 Guipponi M, Scott HS, Chen H, Schebesta A, Rossier C, Antonarakis SE: Two isoforms of a human intersectin (ITSN) protein are produced by brain-specific alternative splicing in a stop codon. Genomics 1998; 53: 369-376.
14 Yamabhai M, Hoffman NG, Hardison NL et al: Intersectin, a novel adaptor protein with two eps15 homology and five src homology 3. J Biol Chem 1998; 273: 31401-31407.

15 Sparks AB, Hoffman NG, McConnell SJ, Fowlkes DM, Kay BK: Cloning of ligand targets: systematic isolation of SH3 domain- containing proteins. Nat Biotechnol 1996; 14 741-744.

16 Chen H, Antonarakis SE: The SH3D1A gene maps to human chromosome 21q22.1-> q22.2. Cytogenet Cell Genet 1997; 78: 213-215.

17 Katsanis N, Beck JA, Fisher EM: Mapping of a novel SH3 domain protein and two proteins of unknown function to human chromosome 21. Hum Genet 1997; 100: 477-480.

18 Roos J, Kelly RB: Dap160, a neural-specific Eps15 homology and multiple SH3 domain- containing protein that interacts with Drosophila dynamin. J Biol Chem 1998; 273: 19108-19119.

19 Salcini AE, Confalonieri S, Doria $\mathrm{M}$ et al: Binding specificity and in vivo targets of the $\mathrm{EH}$ domain, a novel protein-protein interaction module. Genes Dev 1997; 11: 2239-2249.

20 Tebar F, Sorkina T, Sorkin A, Ericsson M, Kirchhausen T: Eps15 is a component of clathrin-coated pits and vesicles and is located at the rim of coated pits. J Biol Chem 1996; 271: $28727-28730$.

21 Benedetti H, Raths S, Crausaz F, Riezman H: The END3 gene encodes a protein that is required for the internalization step of endocytosis and for actin cytoskeleton organization in yeast. Mol Biol Cell 1994; 5: 1023-1037.

22 Mayer BJ, Gupta R: Functions of SH2 and SH3 domains. Curr Top Microbiol Immunol 1998; 228: 1-22.

23 Musacchio A, Saraste M, Wilmanns M: High-resolution crystal structures of tyrosine kinase SH3 domains complexed with proline-rich peptides. Nat Struct Biol 1994; 1: 546-551.

24 Cerione RA, Zheng Y: The Dbl family of oncogenes. Curr Opin Cell Biol 1996; 8: 216-222.

25 Lemmon MA, Ferguson KM, Schlessinger J: PH domains: diverse sequences with a common fold recruit signaling molecules to the cell surface. Cell 1996; 85: 621-624.

26 Shaw G: The pleckstrin homology domain: an intriguing multifunctional protein module. Bioessays 1996; 18 $35-46$.

27 Nalefski EA, Falke JJ: The C2 domain calcium-binding motif: structural and functional diversity. Protein Sci 1996 5: $2375-2390$

28 Schultz J, Milpetz F, Bork P, Ponting CP: SMART, a simple modular architecture research tool: identification of signaling domains. Proc Natl Acad Sci USA 1998; 95: 5857-5864.

29 Strehlau J, Pavlakis M, Lipman M et al: Quantitative detection of immune activation transcripts as a diagnostic tool in kidney transplantation. Proc Natl Acad Sci USA 1997; 94: 695-700.

30 Alcantara S, Ruiz M, M'Arcangelo G et al: Regional and cellular patterns of reelin mRNA expression in the forebrain of the developing and adult mouse. $J$ Neurosci 1998; 18: 7779-7799.

31 Lennon G, Auffray C, Polymeropoulos M, Soares MB: The I.M.A.G.E. Consortium: an integrated molecular analysis of genomes and their expression. Genomics 1996; 33 151-152. 
32 Fuentes JJ, Pritchard MA, Planas AM, Bosch A, Ferrer I, Estivill X: A new human gene from the Down syndrome critical region encodes a proline-rich protein highly expressed in fetal brain and heart. Hum Mol Genet 1995; 4: 1935-1944.

33 Cremona O, De Camilli P: Synaptic vesicle endocytosis. Curr Opin Neurobiol 1997; 7: 323-330.

34 Chen H, Fre S, Slepnev VI et al: Epsin is an EH-domainbinding protein implicated in clathrin-mediated endocytosis. Nature 1998; 394: 793-797.

35 Whitehead IP, Campbell S, Rossman KL, Der CJ: Dbl family proteins. Biochim Biophys Acta 1997; 1332: F1-23.

36 Lamaze C, Chuang TH, Terlecky LJ, Bokoch GM, Schmid SL: Regulation of receptor-mediated endocytosis by Rho and Rac. Nature 1996; 382: 177-179.

37 Sutton RB, Davletov BA, Berghuis AM, Sudhof TC, Sprang SR: Structure of the first C2 domain of synaptotagmin I: a novel $\mathrm{Ca} 2+/$ phospholipid-binding fold. Cell 1995; 80: 929-938.

38 Zigmond AS, Bloom FE, Landis SC, Roberts JL, Squire LR: Fundamental Neuroscience. Academic Press: San Diego, California, USA, 1999.
39 Becker LE, Mito T, Takashima S, Onodera K, Friend WC: Association of phenotypic abnormalities of Down syndrome with an imbalance of genes on chromosome 21 . APMIS Suppl 1993; 40: 57-70.

40 Wisniewski KE: Down syndrome children often have brain with maturation delay, retardation of growth, and corticasl dysgenesis. Am J Med Genet Suppl 1990; 7: 274-281.

41 Dierssen M, Vallina IF, Baamonde C, Garcia-Calatayud S, Lumbreras MA, Florez J: Alterations of central noradrenergic transmission in TS65Dn mouse, a model for Down syndrome. Brain Res 1997; 749: 238-244.

42 Dierssen M, Vallina IF, Baamonde C et al: Impaired cyclic AMP production in the hippocampus of a Down syndrome murine model. Brain Res Dev Brain Res 1996; 95: 122-124.

43 Siarey RJ, Stoll J, Rapoport SI, Galdzicki Z: Altered longterm potentiation in the young and old Ts65Dn mouse, a model for Down Syndrome. Neuropharmacology 1997; 36 $1549-1554$. 